\title{
In vitro anticancer and antioxidant effects of acetone extract of Eucommia ulmoides oliver leaves
}

\author{
Man-Jin $\mathrm{In}^{1} \cdot$ Eun Jeong $\mathrm{Kim}^{2} \cdot$ Dong Chung Kim² \\ 두충잎 아세톤 추출물의 in vitro 항암 및 항산화 효과
}

인만진 ${ }^{1} \cdot$ 김은정 ${ }^{2} \cdot$ 김동청 ${ }^{2}$

Received: 19 February 2018 / Accepted: 20 March 2018 / Published Online: 30 June 2018

(C) The Korean Society for Applied Biological Chemistry 2018

\begin{abstract}
In vitro anticancer and antioxidant effects of acetone extract from leaves of Eucommia ulmoides Oliver were investigated. The extraction yield and total phenolic content of the acetone extract were $1.13 \pm 0.033 \%(\mathrm{w} / \mathrm{w})$ and $36.7 \pm 1.96 \mathrm{mg}$ gallic acid equivalents/g-extract, respectively. $\mathrm{GI}_{50}$ values of the acetone extract for human non-small cell lung cancer cells (A549), human colon cancer cells (SNU-C4), human cervical cancer cells (HeLa), and human embryonic lung epithelial cell (L132) were 53.4, 53.8, 88.3 , and $153.9 \mu \mathrm{g} / \mathrm{mL}$, respectively. The acetone extract effectively inhibited the proliferation of human non-small cell lung cancer (A549) and colon cancer (SNU-C4) cells in a concentrationdependent manner, but was less cytotoxic with human normal cells (L132). $\mathrm{EC}_{50}$ values of the acetone extract for free radical scavenging, reducing power, and lipid peroxidation inhibition were about $2,000,275.8$, and $257.9 \mu \mathrm{g} / \mathrm{mL}$, respectively. The acetone extract showed a potent reducing power and lipid peroxidation inhibitory activity in a concentration-dependent manner.
\end{abstract}

Keywords Acetone extract $\cdot$ Anticancer $\cdot$ Antioxidant $\cdot$ Eucommia ulmoides $\cdot$ Total phenolic

Dong Chung Kim $(\bowtie)$

E-mail:kimdc@chungwoon.ac.kr

${ }^{1}$ Department of Human Nutrition and Food Science, Chungwoon University, Hongseong 32244, Republic of Korea

${ }^{2}$ Department of Chemical Engineering, Chungwoon University, Incheon 22100, Republic of Korea

This is an Open Access article distributed under the terms of the Creative Commons Attribution Non-Commercial License (http://creativecommons. org/licenses/by-nc/3.0/) which permits unrestricted non-commercial use, distribution, and reproduction in any medium, provided the original work is properly cited.

\section{서 론}

두충(Du-zhong, Eucommia ulmoides Oliver)은 잎, 껍질, 줄기 및 열매의 뛰어난 약리 활성으로 인해 우리나라를 비롯한 동아시아 전역에서 널리 사용되어 온 생약재이다[1]. 두충에는 bisepoxylignan, monoepoxylignan 등의 리그닌 성분과 iridoid, 다당체, 스테로이 드, 테르페노이드 등이 함유되어 있으며, 중요한 생리활성 성분 으로는 quercetin, rutin, astragalin, geniposidic acid 등이 알려 져 있다 $[2,3,4]$.

두충잎차는 체지방을 감소시키고 에너지 대사를 촉진하는 것 으로 알려졌고[5], 두충잎과 껍질의 물 추출물은 혈압을 낮추는 활성이 있었다[6]. 두충잎과 껍질의 물 추출물은 간에서 지방과 콜레스테롤의 합성을 억제함으로써 고지혈증의 완화에 도움을 주고, 두충잎 추출물은 동물 실험에서 체중 감량과 백색 지방 조직 감소 등의 항비만 효과가 있었다[7,8]. 민간에서 두충껍질의 물 추출물은 골다공증을 완화하는데 사용되어 왔는데 실제로 동 물 실험에서 두충껍질 추출물이 조골세포를 활성화하고 파골세 포를 감소시킴으로써 뼈의 용해를 억제한다고 보고되었다[9]. 또 한 두충껍질의 물과 메탄올 추출물은 항균과 항염증 활성을 나 타내었고[10,11], 물과 에탄올 추출물은 acetylcholinesterase 활 성 억제를 통한 신경보호 작용[12]과 함께 간의 지방 축적을 억 제함으로써 간 보호 효과를 가지고 있었다[13].

특히 두충잎은 껍질, 꽃, 열매에 비해 강한 항산화 활성을 가 지고 있으며[14], 두충잎의 rutin, chlorogenic acid, ferulic acid 등의 페놀성 화합물이 항산화 활성을 나타내는 주요 물질로 보 고되었다[5]. 두충잎 물 추출물은 껍질에 비해 우수한 지질과산 화 억제 활성을 가지고 있었고[15], 또한 제2형 당뇨병을 유발 한 쥐에서 적혈구의 superoxide dismutase, catalase 및 glutathione peroxidase의 활성을 촉진함으로써 과산화수소와 지질과산화물 의 수준을 낮추는 항산화 활성을 나타내었다[16]. 두충의 잎, 껍 질 및 씨앗을 에탄올로 추출하여 항산화 활성을 비교한 결과, 
두충잎의 폴리페놀 및 플라보노이드 함량이 가장 높았고, 이와 비례하여 유리라디칼 소거활성, 환원력 및 지질과산화 억제활성 도 두충잎 에탄올 추출물에서 높게 나타났다[17]. 두충잎의 물 추출물이 $\mathrm{DNA}$ 와 같은 생체 고분자의 산화적 손상을 방지하는 항산화 활성을 가지고 있어 장기적으로 항암 효과를 나타낼 것 으로 보고되었다[18].

일반적으로 천연물의 추출 용매로 물과 에탄올이 주로 사용 되고 있어 비극성 용매에서 추출되는 지용성 성분에 대한 연구 는 미흡한 실정이다. 실제로 약용 식물의 지용성 추출물이 암 세포의 증식을 효과적으로 억제한다는 많은 보고[19,20,21,22]가 있고, 두충잎의 경우에도 석유에테르 추출물이 in vitro에서 사 람의 결장암세포(HCT-116)의 증식을 억제한다고 알려져 있어 [23], 이를 근거로 비극성 용매를 사용하여 두충잎의 지용성 추 출물을 얻고 생리활성을 확인하고자 하였다. 따라서 본 연구에 서는 예비실험을 통해 항암 활성이 뛰어난 것으로 나타난 두충 잎의 아세톤 추출물을 대상으로 암세포 증식억제 활성을 확인 하였고, 이와 함께 페놀성 화합물 함량, 유리라디칼 소거능, 환 원력 및 지질과산화 억제능을 확인함으로써 두충잎의 생리활성 소재로서의 용도 확대에 기여하고자 하였다.

\section{재료 및 방법}

\section{실험 재료}

두충잎 분말은 그린내츄럴(Jindo, Korea)에서 구입하여 사용하 였다. Folin-Ciocalteu reagent, gallic acid, 2,2-diphenyl-1picryl-hydrazyl (DPPH), ferric ferricyanide, $\alpha$-tocopherol 및 indole-3-carbinol은 Sigma-Aldrich (St. Louis, MO, USA) 제 품을 사용하였다. 인체 비소세포폐암세포(human non-small cell lung cancer cell, A549), 결장암세포(human colon cancer cell, SNU-C4), 자궁경부암세포(human cervical cancer cell, HeLa) 및 인체 배아 폐 상피세포(human embryonic lung epithelial cell, L132)는 American Type Culture Collection (Manassa, VA, USA)의 세포주를 배양하여 사용하였다. RPMI-1640, fetal bovine serum (FBS), penicillin-streptomycin 및 trypsin-EDTA 는 HyClone (Logan, UT, USA)의 제품을, Cell Counting Kit-8 (CCK-8)은 Dojindo (Kumamoto, Japan)의 제품을 사용하였다.

\section{아세톤 추출물 제조}

두충잎 분말은 $60^{\circ} \mathrm{C}$ 에서 4시간 건조한 후 재분쇄하여 100-300 $\mu \mathrm{m}$ 크기의 입자만을 시료로 사용하였다. 두충잎 분말에 10 배 (w/w)의 아세톤을 넣고 항온진탕조(Jeio Tech, Daejeon, Korea) 를 사용하여 상온에서 2시간 동안 추출하였다. 상온에서 원심 분리 $(2,000 \times g, 5$ 분 $)$ 하여 상징액을 얻고 $60^{\circ} \mathrm{C}$ 에서 아세톤을 증발 시켜 두충잎 아세톤 추출물을 제조하였다.

\section{총 페놀성 화합물 함량}

두충잎 아세톤 추출물의 총 페놀성 화합물 함량은 FolinCiocalteu reagent를 사용하여 측정하였다[24]. 두충잎 추출물에 Folin-Ciocalteu 시약을 부가하여 상온에서 3 분간 반응시키고, $10 \% \mathrm{Na}_{2} \mathrm{CO}_{3}$ 용액을 넣고 상온에서 1시간 정치시킨 후 $725 \mathrm{~nm}$
에서의 흡광도를 측정하였다. 총 폴리페놀 함량은 $\mathrm{mg}$ gallic acid equivalent $(\mathrm{GAE}) / \mathrm{g}$-추출물로 나타내었다.

\section{In vitro 항암 활성}

두충잎 아세톤 추출물의 암세포 증식억제 활성은 CCK-8을 이 용하여 측정하였다[25]. 두충잎 추출물을 에탄올에 용해한 뒤 배지에 희석하여 사용하였고, 이때 에탄올의 최종 농도가 $0.1 \%$ (v/v)이 초과되지 않도록 하였다. 암세포(A549, SNU-C4, HeLa) 와 정상세포(L132)는 5\% FBS와 penicillin-streptomycin이 포함 된 RPMI- 1640 배지에서 $5 \% \quad \mathrm{CO}_{2}, 37^{\circ} \mathrm{C}$ 의 조건으로 24 시간 배양하였다. 이후 배양액을 신선한 배지로 교체한 뒤 희석한 두 충잎 추출물을 농도별로 처리하고 동일 조건에서 배양하였다. 양성대조군인 indol-3-carbinol을 농도별로 처리하여 암세포 증 식억제 활성을 비교하였다. 24 시간 후 실험군과 대조군의 배양 액을 제거한 후 각각 CCK-8 용액과 serum-free RPMI-1640을 첨가하여 microplate reader (Molecular Devices, Sunnyvale, $\mathrm{CA}, \mathrm{USA}$ )로 $450 \mathrm{~nm}$ 에서 흡광도를 측정하였다[20]. 암세포 증 식억제 활성 $(\%)$ 은 (대조군의 흡광도-실험군의 흡광도)/대조군 의 흡광도 $\times 100$ 으로 계산하였다.

\section{In vitro 항산화 활성}

두충잎 아세톤 추출물의 유리라디칼 소거활성은 $\mathrm{DPPH}$ 를 사용 하여 측정하였다[26]. 농도별로 희석한 두충잎 추출물에 0.15 $\mathrm{mM} \mathrm{DPPH}$ 용액을 첨가하고 상온에서 30 분 반응시킨 후 525 $\mathrm{nm}$ 에서 흡광도를 측정하였다. 유리라디칼 소거활성 $(\%)$ 은 (무첨 가군의 흡광도-첨가군의 흡광도)/무첨가군의 흡광도 $\times 100$ 으로 계 산하였고, 양성대조군으로 $\alpha$-tocopherol을 사용하였다.

두충잎 아세톤 추출물의 환원력은 ferric ferricyanide를 사용 하여 측정하였다[27]. 농도별로 희석한 두충잎 추출물에 $1 \%$ $\mathrm{K}_{3} \mathrm{Fe}(\mathrm{CN})_{6}$ 과 $0.2 \mathrm{M}$ 인산 완충용액 $(\mathrm{pH} 6.6)$ 을 첨가하여 $50^{\circ} \mathrm{C}$ 에 서 20 분간 반응시킨 후 $10 \%$ trichloroacetic acid 용액을 가하 고 $2,000 \times \mathrm{g}$ 에서 5 분간 원심분리하였다. 상징액을 얻어 $0.1 \%$ $\mathrm{FeCl}_{3}$ 용액을 가한 후 $700 \mathrm{~nm}$ 에서 흡광도를 측정하였다. 환원력 은 흡광도 값으로 나타내었고, 양성대조군으로 $\alpha$-tocopherol을 사용하였다.

두충잎 아세톤 추출물의 지질과산화 억제활성은 linoleic acid 의 산화에 의해 생성되는 과산화물의 측정법으로 확인하였다 [28]. 농도별로 희석한 두충잎 추출물에 $2.52 \mathrm{mg} / \mathrm{mL}$ linoleic acid와 $50 \mathrm{mM}$ 인산 완충액 $(\mathrm{pH} 7.0) 4.0 \mathrm{~mL}$ 을 혼합하여 $45^{\circ} \mathrm{C}$ 에 서 48시간 동안 반응시켰다. 시료를 채취하여 $30 \%$ ammonium thiocyanate와 함께 $75 \%$ ethanol 용액에 혼합한 후 실온에서 5 분간 정치시키고 $20 \mathrm{mM}$ ferrous chloride를 첨가하여 $500 \mathrm{~nm}$ 에 서 흡광도를 측정하였다. 지질과산화 정도는 흡광도 값으로 나 타내었고, 양성대조군으로 $\alpha$-tocopherol을 사용하였다.

\section{통계처리}

두충잎 아세톤 추출물을 처리한 시료에 대해 t-test를 실시하여 유의성을 검증하였다. 세 번의 반복실험을 통해 얻어진 결과를 평균 \pm 표준편차로 나타내었고, $p<0.05$ 인 경우 통계적으로 유의 한 것으로 판정하였다. 


\section{결과 및 고찰}

\section{두충잎 아세톤 추출물의 수율 및 총 페놀성 화합물 함량}

두충잎을 아세톤으로 추출하여 얻어진 고형분의 수율은 $1.13 \pm$ $0.033 \%(\mathrm{w} / \mathrm{w})$ 로 매우 낮게 나타났다(Table 1). 일반적으로 천연 물을 비극성 용매로 추출하는 경우 당류, 무기질 및 단백질 등 의 극성 분자들이 잘 추출되지 않아 수율이 낮아진다[22]. 인삼 과 홍삼을 메탄올, 에탄올, 아세톤 및 $\mathrm{n}$-헥산으로 추출하였을 때 도 수율이 20.78 에서 $0.41 \%$ 까지 비극성 용매로 갈수록 급격하 게 감소하였다[29]. 두충잎 아세톤 추출물의 총 페놀성 화합물 함량은 추출물 $\mathrm{g}$ 당 $36.7 \pm 1.96 \mathrm{mg} \mathrm{GAE}$ (Table 1)로 기존에 알 려진 두충잎 물 추출물의 페놀성 화합물 함량인 $75.8-110 \mathrm{mg}$ $\mathrm{GAE} / \mathrm{g}$ 에 비해서 2배 이상 낮게 나타났다[30]. 이러한 결과는 극성 용매에서 페놀성 화합물의 추출이 잘 되고 비극성 용매로 갈수록 수율이 낮아진다는 보고와 같은 경향을 보여주었다 [21,22].

\section{두충잎 아세톤 추출물의 in vitro 항암 활성}

사람의 비소세포폐암(A549), 결장암(SNU-C4) 및 자궁경부암 (HeLa) 세포를 대상으로 두충잎 아세톤 추출물의 in vitro 항암 활성을 확인하였다[21,22]. 암세포 증식억제 활성의 양성대조군 으로는 항암 효과를 가진 물질인 indole-3-carbinol을 사용하였 고[31], 정상세포에 대한 독성을 확인하기 위해 사람의 배아 폐 상피세포(L132)를 사용하였다[21,22]. 두충잎 아세톤 추출물은 농도의 증가에 비례하여 사람의 비소세포폐암세포(A549), 결장 암세포(SNU-C4) 및 자궁경부암세포(HeLa)의 증식을 억제하였 다(Fig. 1). 암세포의 증식을 절반 억제하는 농도인 $\mathrm{GI}_{50}$ 값은 비 소세포폐암세포(A549)에서 $53.4 \mu \mathrm{g} / \mathrm{mL}$ 였고, 결장암세포(SNU$\mathrm{C} 4)$ 에서 $53.8 \mu \mathrm{g} / \mathrm{mL}$ 로 암세포 증식억제 효과가 매우 높았지만, 자궁경부암세포(HeLa)에 대해서는 $88.3 \mu \mathrm{g} / \mathrm{mL}$ 로 상대적으로 낮 게 나타났다(Table 2). 양성대조군인 indole-3-carbinol의 암세포 증식억제에 대한 $\mathrm{GI}_{50}$ 값은 비소세포폐암세포(A549)에서 $52.4 \mu \mathrm{g}$ / $\mathrm{mL}$, 결장암세포(SNU-C4)에서 $30.3 \mu \mathrm{g} / \mathrm{mL}$ 및 자궁경부암세포 (HeLa)에서 $64.7 \mu \mathrm{g} / \mathrm{mL}$ 으로 두충잎 추출물에 비해 낮았다(Table 2). 따라서 두충잎 아세톤 추출물의 암세포 증식억제 활성은 단 일 성분인 indole-3-carbinol에 비해 다소 낮게 나타났으나 두충 잎 추출물이 여러 성분이 섞여있는 혼합물인 점을 고려한다면 항암 활성이 우수하다고 볼 수 있다[22]. 사람의 비소세포폐암 세포(A549)에 대한 $\mathrm{GI}_{50}$ 값을 비교하였을 때, 인삼의 $\mathrm{n}$-헥산 추 출물은 $20.0 \mu \mathrm{g} / \mathrm{mL}$ 이었고( $\mathrm{In}$ 등, 2014), 유근피 아세톤 추출물 은 $74.3 \mu \mathrm{g} / \mathrm{mL}$ 이었다[22]. 또한 12 종의 중국산 약용 식물의 수
Table 1 Yield and total phenolic content of acetone extract of Eucommia ulmoides leaves

\begin{tabular}{cc}
\hline \hline Yield (\%) & Total phenolic content ${ }^{2)}(\mathrm{mg} \mathrm{GAE} / \mathrm{g})$ \\
\hline $1.13 \pm 0.033^{1)}$ & $36.7 \pm 1.96^{1)}$ \\
\hline${ }^{1)}$ Data represent means and SD of triplicate measurements
\end{tabular}

${ }^{2)}$ Total phenolic content was expressed as gallic acid equivalents (GAE)

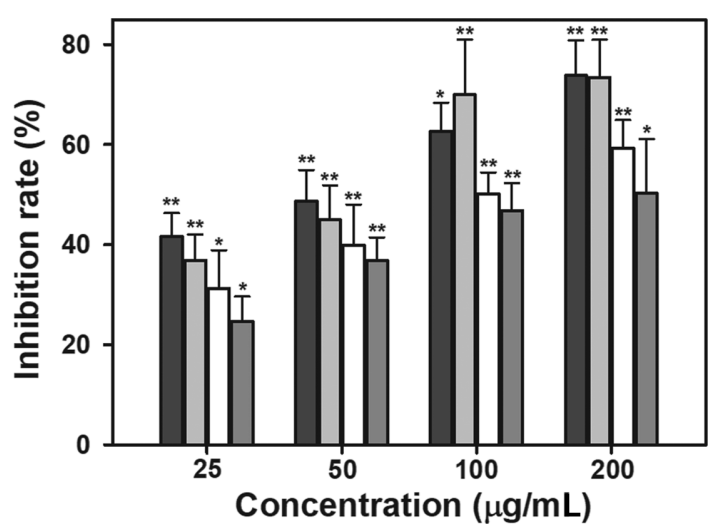

Fig. 1 Effects of acetone extract of Eucommia ulmoides leaves on human non-small cell lung cancer (A549, black bar), colon cancer (SNU-C4, gray bar), cervical cancer (HeLa, white bar), and embryonic lung epithelial (L132, dark gray bar) cells proliferation. Data were means and SD of triplicate measurements. ${ }^{*} p<0.05$ and ${ }^{* *} p<0.01$ compared to the values for untreated control

용성 추출물들의 비소세포폐암세포(A549)에 대한 $\mathrm{GI}_{50}$ 값은 $161-$ $1,456 \mu \mathrm{g} / \mathrm{mL}$ 로 나타나[32], 두충잎 아세톤 추출물은 인삼의 지 용성 추출물을 제외한 다른 천연 추출물들에 비해 상대적으로 우수한 in vitro 항암 활성을 가지고 있음을 보여주었다.

또한 두충잎 아세톤 추출물은 사람의 정상세포인 배아 폐 상피 세포(L132)에 대한 $\mathrm{GI}_{50}$ 값이 $153.9 \mu \mathrm{g} / \mathrm{mL}$ 로 높게 나타나(Table 2), 정상 세포에 대한 독성이 상대적으로 낮으면서도 암세포에 대한 증식억제 활성이 우수함을 보여주었다. 식물로부터 얻어진 페놀성 화합물은 뛰어난 항암 활성을 가지고 있고[33], 페놀성 화합물의 항암 활성은 세포자살 유도, 세포주기 진행 억제, 신 생혈관 생성 억제 및 전이 억제 작용에 의한 것으로 보고되었 다[33,34]. 특히 페놀성 화합물 중 플라보노이드계 페놀화합물 의 암세포 증식억제 활성이 우수하다고 알려져 있다[35]. 두충 잎에는 뛰어난 항암활성을 가진 rutin과 quercetin이 플라보노이 드계 페놀화합물의 주 성분을 이루고 있는데[30,36,37], 이들 중

Table 2 Inhibitory effect of acetone extract of Eucommia ulmoides leaves on cell growth

\begin{tabular}{|c|c|c|c|}
\hline & \multirow{2}{*}{ Human cell lines } & \multicolumn{2}{|c|}{$\mathrm{GI}_{50}$ values $^{1)}(\mu \mathrm{g} / \mathrm{mL})$} \\
\hline & & E. ulmoides extract & Indole-3-carbinol $^{2)}$ \\
\hline \multirow{3}{*}{ Cancer cell } & Non-small cell lung cancer cell (A549) & $53.4 \pm 2.33^{3)}$ & $52.4 \pm 4.49$ \\
\hline & Colon cancer cell (SNU-C4) & $53.8 \pm 16.1$ & $30.3 \pm 7.00$ \\
\hline & Cervical cancer cell (HeLa) & $88.3 \pm 10.09$ & $64.7 \pm 9.38$ \\
\hline Normal cell & Embryonic lung epithelial cell (L132) & $153.9 \pm 31.75$ & $75.6 \pm 1.26$ \\
\hline
\end{tabular}

${ }^{1)} \mathrm{GI}_{50}$ values represent the concentration of acetone extract that caused $50 \%$ growth inhibition of cells

${ }^{2}$ Indole-3-carbinol was used as a positive control

${ }^{3)}$ Data represent means and SD of triplicate measurements 

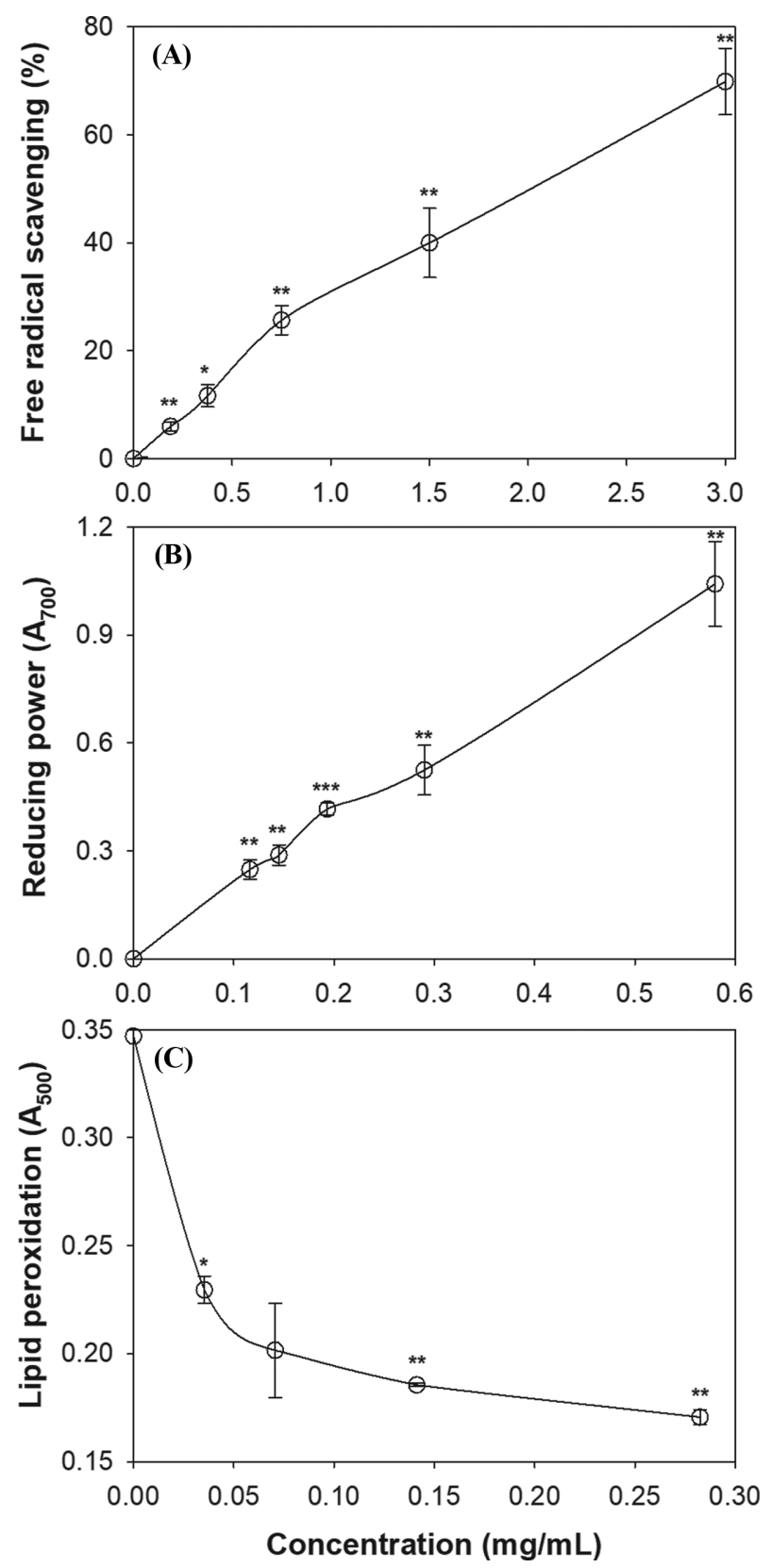

Fig. 2 In vitro antioxidant activities of acetone extract of Eucommia ulmoides leaves. (A) DPPH free radical scavenging activity, (B) Reducing power, (C) Lipid peroxidation inhibitory activity. Data were means and SD of triplicate measurements. ${ }^{*} p<0.05,{ }^{* *} p<0.01$, and $* * * p$ $<0.001$ compared to the values for untreated control

물 보다는 유기용매에 잘 추출되는 소수성 페놀화합물인 quercetin 이 두충잎 아세톤 추출물의 암세포 증식억제에 크게 기여하는 것으로 사료된다[30,38].

\section{두충잎 아세톤 추출물의 in vitro 항산화 활성}

두충잎 아세톤 추출물의 항산화 활성을 확인하기 위해 유리라 디칼 소거활성, 환원력 및 지질과산화 억제활성을 측정하였고, 양성대조군으로 지용성의 천연 항산화제인 $\alpha$-tocopherol을 사용
Table 3 Antioxidant effect of acetone extract of Eucommia ulmoides leaves

\begin{tabular}{lcc}
\hline \hline \multirow{1}{*}{ Antioxidant activity } & \multicolumn{2}{c}{ EC $_{50}$ values $^{1)}(\mathrm{ig} / \mathrm{mL})$} \\
\cline { 2 - 3 } & E. ulmoides extract & $\alpha$-tocopherol ${ }^{2}$ \\
\hline $\begin{array}{l}\text { DPPH free radical } \\
\text { scavenging activity }\end{array}$ & $2,077.8 \pm 212.54^{3)}$ & $85.1 \pm 15.41$ \\
$\begin{array}{l}\text { Reducing power } \\
\text { Lipid peroxidation inhibitory } \\
\text { activity }\end{array}$ & $275.8 \pm 33.26$ & $71.9 \pm 3.28$ \\
\hline
\end{tabular}

${ }^{1)} \mathrm{EC}_{50}$ values for free radical scavenging activity, reducing power, and lipid peroxidation inhibitory activity are expressed as the effective concentrations at which $50 \%$ of DPPH free radicals were scavenged, at which the absorbance is 0.5 , and at which $50 \%$ of lipid peroxidation was inhibited, respectively

${ }^{2)}$ Alpha-tocopherol was used as a positive control

${ }^{3)}$ Data represent means and SD of triplicate measurements

하였다. 두충잎 아세톤 추출물의 DPPH 유리라디칼 소거활성은 농도에 비례하여 증가하였으나(Fig. 2A), DPPH 유리라디칼을 절반 소거하는 농도인 $\mathrm{EC}_{50}$ 값이 $\sim 2 \mathrm{mg} / \mathrm{mL}$ 로 높게 나타나 소거 효과가 크지 않음을 알 수 있었다(Table 3). 두충잎 아세톤 추 출물의 유리라디칼 소거에 대한 $\mathrm{EC}_{50}$ 값은 양성대조군인 $\alpha$ tocopherol의 $\mathrm{EC}_{50}$ 값인 $85.1 \mu \mathrm{g} / \mathrm{mL}$ 에 비해서 크게 높았고(Table $3)$, 다른 식물 추출물의 유리라디칼 소거에 대한 $\mathrm{EC}_{50}$ 값과 비교 하여도 모시잎 에탄올 추출물의 $688 \mu \mathrm{g} / \mathrm{mL}$ [39], 곤드레잎의 물 과 메탄올 추출물의 $87.1-111.19 \mu \mathrm{g} / \mathrm{mL}$ [40], 고구마잎 에탄올 추출물의 $109-168 \mu \mathrm{g} / \mathrm{mL}$ [41], 유근피 아세톤 추출물의 36.7 $\mu \mathrm{g} / \mathrm{mL}$ [22] 및 백연수잎 에탄올 추출물의 $133.51 \mu \mathrm{g} / \mathrm{mL}$ [42] 보다도 매우 높게 나타나 두충잎 아세톤 추출물의 유리라디칼 에 대한 전자공여 능력은 낮은 것으로 확인되었다.

두충잎 아세톤 추출물의 환원력 역시 농도의존적으로 증가하 였고(Fig. $2 \mathrm{~B}$ ), 반응액의 흡광도가 0.5 일 때의 농도인 $\mathrm{EC}_{50}$ 값은 $275.8 \mu \mathrm{g} / \mathrm{mL}$ 이었다(Table 3). 두충잎 아세톤 추출물의 환원력에 대한 $\mathrm{EC}_{50}$ 값은 양성대조군인 $\alpha$-tocopherol의 $71.9 \mu \mathrm{g} / \mathrm{mL}$ 에 비 해 높았으나 두충잎 추출물이 혼합물인 점을 고려하면 우수한 환원력을 가지는 것으로 여겨진다(Table 3). 다른 식물 추출물 의 환원력에 대한 $\mathrm{EC}_{50}$ 값과 비교하였을 때 모시잎 에탄올 추출 물의 $44.39 \mu \mathrm{g} / \mathrm{mL}$ [43]과 유근피 아세톤 추출물의 $53.2 \mu \mathrm{g} / \mathrm{mL}$ [22]에 비해서는 높았으나, 백연수잎 에탄올 추출물의 $250 \mu \mathrm{g} / \mathrm{mL}$ [42]과는 비슷하였고, 오디 아세톤 추출물의 $746 \mu \mathrm{g} / \mathrm{mL}$ [44], 복 분자 아세톤 추출물의 $871 \mu \mathrm{g} / \mathrm{mL}$ [44] 및 자색고구마 에탄올 추출물의 $236 \mu \mathrm{g} / \mathrm{mL}$ [45]보다는 낮은 값을 가져 두충잎 아세톤 추출물의 환원력은 우수한 것으로 판단되었다.

두충잎 아세톤 추출물은 linoleic acid의 과산화를 농도의존적 으로 억제하였고(Fig. 2C), 지질과산화를 절반 저해하는 농도인 $\mathrm{EC}_{50}$ 값은 $257.9 \mu \mathrm{g} / \mathrm{mL}$ 이었다(Table 3). 두충잎 아세톤 추출물의 지질과산화 억제에 대한 $\mathrm{EC}_{50}$ 값은 양성대조군인 $\alpha$-tocopherol의 $126.7 \mu \mathrm{g} / \mathrm{mL}$ 에 비해 높았으나 역시 혼합물인 점을 고려하면 우 수한 지질과산화 억제활성을 가지는 것으로 사료된다(Table 3). 백연수잎 에탄올 추출물의 경우 지질과산화 억제에 대한 $\mathrm{EC}_{50}$ 값이 $\sim 500 \mu \mathrm{g} / \mathrm{mL}$ [42]인 것과 비교하여도 두충잎 추출물의 지 질과산화 억제활성은 우수하였다. 두충잎 아세톤 추출물에 존재 하는 비극성의 페놀성 화합물은 유리라디칼의 소거보다는 세포 
막 지질의 산화적 손상을 억제하는데 효과적으로 여겨지며, 이 는 두충잎의 플라보노이드계 페놀화합물의 주 성분인 quercetin 이 유리라디칼 소거보다는 기름의 산화억제에 높은 상관관계를 가진다는 보고[30]와 유사성을 보여주었다.

이상의 결과에서 두충잎의 아세톤 추출물은 사람의 비소세포 폐암세포 및 결장암세포에 대한 뛰어난 증식억제 활성을 나타 내었고, 환원력과 지질과산화 억제 능력이 우수하여 항암 및 항 산화 소재로서의 활용가능성을 보여주었다.

\section{초 록}

두충(Eucommia ulmoides Oliver)잎 아세톤 추출물의 in vitro 항암 및 항산화 활성을 조사하였다. 두충잎 아세톤 추출물의 수 율은 $1.13 \pm 0.033 \%(\mathrm{w} / \mathrm{w})$ 이었고, 총 페놀성 화합물 함량은 36.7 $\pm 1.96 \mathrm{mg}$ gallic acid equivalents/g-추출물로 나타났다. 세포증식 을 절반 억제하는 추출물의 농도인 $\mathrm{GI}_{50}$ 값은 사람의 암세포인 비소세포폐암세포(A549)에서 $53.4 \mu \mathrm{g} / \mathrm{mL}$, 결장암세포(SNU-C4) 에서 $53.8 \mu \mathrm{g} / \mathrm{mL}$ 및 자궁경부암세포 $(\mathrm{HeLa})$ 에서 $88.3 \mu \mathrm{g} / \mathrm{mL}$ 이었 고, 사람의 정상세포인 배아 폐 상피세포(L132)에서는 $153.9 \mu \mathrm{g} /$ $\mathrm{mL}$ 로 나타났다. 두충잎 아세톤 추출물은 사람의 정상세포에는 낮은 독성을 나타내면서 농도에 비례하여 사람의 비소세포폐암 세포(A549)와 결장암세포(SNU-C4)의 증식을 효과적으로 억제 하였다. DPPH 유리라디칼을 절반 소거하는 추출물의 농도인 $\mathrm{EC}_{50}$ 값은 $2 \mathrm{mg} / \mathrm{mL}$ 정도로 높게 나타났고, 환원력의 $\mathrm{EC}_{50}$ 값은 $275.8 \mu \mathrm{g} / \mathrm{mL}$, 지질과산화를 절반 저해하는 농도인 $\mathrm{EC}_{50}$ 값은 $257.9 \mu \mathrm{g} / \mathrm{mL}$ 이었다. 유근피 아세톤 추출물은 농도에 비례하여 우수한 환원력 및 지질과산화 억제활성을 보여주었다.

Keywords 두충잎 · 아세톤 추출물 - 페놀성 화합물 - 항산화 항암

\section{References}

1. Kwan CY, Chen CX, Deyama T, Nishibe S (2003) Endotheliumdependent vasorelaxant effects of the aqueous extracts of the Eucommia ulmoides Oliv. leaf and bark: implications on their antihypertensive action. Vascul Pharmacol 40: 229-235

2. Hong YK, Liu WJ, Li T, She SY (2013) Optimization of extraction of Eucommia ulmoides polysaccharides by response surface methodology. Carbohydr Polym 92: 1761-1766

3. He X, Wang J, Li M, Hao D, Yang Y, Zhang C, He R, Tao R (2014) Eucommia ulmoides Oliv.: ethnopharmacology, phytochemistry, and pharmacology of an important traditional Chinese medicine. J Ethnopharmacol 151: 78-92

4. Hussain T, Tan B, Oladele OA, Rahu N, Tossou MC, Yin Y (2016) Health-promoting properties of Eucommia ulmoides: a review. Evid Based Complement Alternat Med 2016: 5202908

5. Kulomaa A, Sirén H, Riekkola ML (1997) Identification of antioxidative compounds in plant beverages by capillary electrophoresis with the marker index technique. J Chromatogr A 781: 523-532

6. Greenway F, Liu Z, Yu Y, Gupta A (2011) A clinical trial testing the safety and efficacy of a standardized Eucommia ulmoides Oliver bark extract to treat hypertension. Altern Med Rev 16: 338-347

7. Choi MS, Jung UJ, Kim HJ, Do GM, Jeon SM, Kim MJ, Lee MK
(2008) Du-zhong (Eucommia ulmoides Oliver) leaf extract mediates hypolipidemic action in hamsters fed a high-fat diet. Am J Chin Med 36: 81-93

8. Hirata T, Kobayashi T, Wada A, Ueda T, Fujikawa T, Miyashita H, Ikeda T, Tsukamoto S, Nohara T (2011) Anti-obesity compounds in green leaves of Eucommia ulmoides. Bioorg Med Chem Lett 21: 1786-1791

9. Zhang R, Liu ZG, Li C, Hu SJ, Liu L, Wang JP, Mei QB (2009) DuZhong (Eucommia ulmoides Oliv.) cortex extract prevent OVX-induced osteoporosis in rats. Bone 45: 553-559

10. Kim BH, Park KS, Chang IM (2009) Elucidation of anti-inflammatory potencies of Eucommia ulmoides bark and Plantago asiatica seeds. J Med Food 12: 764-769

11. Tsai TH, Tsai TH, Wu WH, T JTP, Tsai PJ (2010) In vitro antimicrobial and anti-inflammatory effects of herbs against Propionibacterium acnes. Food Chem 119: 964-968

12. Kwon SH, Lee HK, Kim JA, Hong SI, Kim SY, Jo TH, Park YI, Lee CK, Kim YB, Lee SY, Jang CG (2011) Neuroprotective effects of Eucommia ulmoides Oliv. Bark on amyloid beta(25-35)-induced learning and memory impairments in mice. Neurosci Lett 487: 123-127

13. Jin CF, Li B, Lin SM, Yadav RK, Kim HR, Chae HJ (2013) Mechanism of the inhibitory effects of Eucommia ulmoides Oliv. cortex extracts (EUCE) in the $\mathrm{CCl}_{4}$-induced acute liver lipid accumulation in rats. Int $\mathrm{J}$ Endocrinol 2013: 751854

14. Zhang Q, Su YQ, Yang FX, Peng JN, Li XH, Sun RC (2007) Antioxidative activity of water extracts from leaf, male flower, raw cortex and fruit of Eucommia ulmoides Oliv. Forest Products J 57: 74-78

15. Yen GC, Hsieh CL (1998) Antioxidant activity of extracts from Duzhong (Eucommia ulmoides) toward various lipid peroxidation models in vitro. J Agric Food Chem 46: 3952-3957

16. Park SA, Choi MS, Jung UJ, Kim MJ, Kim DJ, Park HM, Park YB, Lee MK (2006) Eucommia ulmoides Oliver leaf extract increases endogenous antioxidant activity in type 2 diabetic mice. J Med Food 9: 474-479

17. Xu Z, Tang M, Li Y, Liu F, Li X, Dai R (2010) Antioxidant properties of Du-zhong (Eucommia ulmoides Oliv.) extracts and their effects on color stability and lipid oxidation of raw pork patties. J Agric Food Chem 58: 7289-7296

18. Hsieh CL, Yen GC (2000) Antioxidant actions of Du-zhong (Eucommia ulmoides Oliv.) toward oxidative damage in biomolecules. Life Sci 66: 1387-1400

19. Yang SJ, Cho SH, Cho SI, Na WM (2007) Anti-proliferative effect of Ulmi pumilae cortex extracts on MCF-7 cells. J Orient Obstet Gynecol 20: $35-44$

20. Lee SD, Yoo G, Chae HJ, In MJ, Oh NS, Hwang YK, Hwang WI, Kim DC (2009) Lipid-soluble extracts as the main source of anticancer activity in ginseng and ginseng marc. J Am Oil Chem Soc 86: 10651071

21. In MJ, Chae HJ, Kim DC (2014) In vitro antioxidant and anticancer potential of n-hexane extract from ginseng marc. J Appl Biol Chem 57: 247-250

22. In MJ, Kim DC (2016) Anti-oxidative and anti-proliferative activities of acetone extract of the cortex of Ulmus pumila L. J Appl Biol Chem 59: $133-136$

23. Kim JB, Park JR, Jeon JR, Cha MH (2001) Isolation and identification of anticancer compounds from Eucommia ulmoides leaves. J Korean Soc Food Sci Nutr 30: 732-738

24. Folin O, Denis W (1912) On phosphotungstic-phosphomolybdic compounds as color reagents. J Biol Chem 12: 239-243

25. Itano N, Atsumi F, Sawai T, Yamada Y, Miyaishi O, Senga T, Hamaguchi M, Kimata K (2002) Abnormal accumulation of hyaluronan matrix diminishes contact inhibition of cell growth and promotes cell migration. Proc Natl Acad Sci USA 99: 3609-3614

26. Blois MS (1958) Antioxidant determination by the use of a stable free radical. Nature 181: 1199-1200

27. Oyaizu M (1985) Studies on products of browning reaction: antioxidant 
activities of products of browning reaction prepared from glucosamine. Jap J Nutr 44: 307-315

28. Nakatani N, Kikuzaki H (1987) A new antioxidative glucoside isolated from oregano (Origanum vulgare L.). Agric Biol Chem 51: 2727-2732

29. Choi KJ, Kim MW, Hong SK, Kim DH (1983) Effect of solvents on the yield, brown color intensity, UV absorbance, reducing and antioxidant activities of extracts from white and red ginseng. J Korean Agric Chem Soc 26: $8-18$

30. Zhang Q, Su Y, Zhang J (2013) Seasonal difference in antioxidant capacity and active compounds contents of Eucommia ulmoides Oliver leaf. Molecules 18: 1857-1868

31. Weng JR, Tsai CH, Kulp SK, Chen CS (2008) Indole-3-carbinol as a chemopreventive and anti-cancer agent. Cancer Lett 262: 153

32. Shoemaker M, Hamilton B, Dairkee SH, Cohen I, Campbell MJ (2005) In vitro anticancer activity of twelve Chinese medicinal herbs. Phytother Res 19: 649-651

33. Niedzwiecki A, Roomi MW, Kalinovsky T, Rath M (2016) Anticancer efficacy of polyphenols and their combinations. Nutrients 8: 552

34. Lamoral-Theys D, Pottier L, Dufrasne F, Nève J, Dubois J, Kornienko A, Kiss R, Ingrassia L (2010) Natural polyphenols that display anticancer properties through inhibition of kinase activity. Curr Med Chem 17: 812-825

35. Ravishankar D, Rajora AK, Greco F, Osborn HM (2013) Flavonoids as prospective compounds for anti-cancer therapy. Int J Biochem Cell Biol 45: $2821-2831$

36. Dixit S (2014) Anticancer effect of rutin isolated from the methanolic extract of Triticum aestivum straw in mice. Med Sci 2: 153-160

37. Khan F, Niaz K, Maqbool F, Hassan FI, Abdollahi M, Venkata KCN,
Nabavi SM, Bishayee A (2016) Molecular targets underlying the anticancer effects of quercetin: an update. Nutirents 8: 529

38. Asgary S, Naderi GH, N Askari N (2005) Protective effect of flavonoids against red blood cell hemolysis by free radicals. Exp Clin Cardiol 10: $88-90$

39. Nho JW, Hwang IG, Kim HY, Lee YR, Woo KS, Hwang BY, Chang SJ, Lee J, Jeong HS (2010) Free radical scavenging, angiotensin Iconverting enzyme (ACE) inhibitory, and in vitro anticancer activities of ramie (Boehmeria nivea) leaves extracts. Food Sci Biotechnol 19: 383 390

40. Lee YM, Bae JH, Jung HY, Kim JH, Park DS, Jung HY (2011) Antioxidant activity in water and methanol extracts from Korean edible wild plants. J Korean Soc Food Sci Nutr 40: 29-36

41. Li M, Jeong HS, Kim HS, Jang GY, Woo KS, Lee SH, Lee J, Sin HM (2012) Chemical compositions and antioxidant activities of leaves and stalks from different sweet potato cultivars. J Korean Soc Food Sci Nutr 41: $1656-1662$

42. Kim DC, In MJ (2017) Antioxidative ability of ethanol extract from the leaves of Leucaena leucocephala (Lam.) de Wit. J Appl Biol Chem 60: 185-190

43. Kim C, In MJ, Kim DC (2015) In vitro antioxidant activity of ethanol extract from Boehmeria nivea L. leaves. Food Eng Prog 19: 76-81

44. Jun HI, Kim YA, Kim YS (2014) Antioxidant activities of Rubus coreanus Miquel and Morus alba L. fruits. Korean Soc Food Sci Nutr 43: $381-388$

45. Kim DC, Kim C, In MJ (2015) Antioxidant activities of extracts prepared from sweet potatoes with different flesh colors. J Appl Biol Chem 58: 21-24 